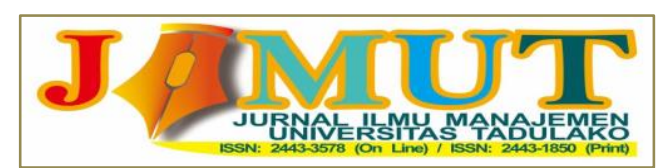

Vol. 6, No.3, September 2020, 272-278

\title{
Analisis Pengaruh Capital Adequancy Ratio, Debt to Equity Ratio, Loan to Deposit Ratio, dan Earning Per Share Terhadap Return On Asset
}

\author{
Marli \\ mr_marli@yahoo.com
}

\begin{abstract}
Abstrak
Hasil penelitian nilai koefisien determinasi $\left(\mathrm{R}^{2}\right)$ sebesar 0,618 koefisien korelasi berganda (R) 0,786 menunjukkan bahwa sumbangan yang diberikan variabel bebas yaitu tCapital Adequancy Ratio, Debt To Equity Ratio,Loan To Deposit Ratiodan Earning Per Share terhadap return on assets sebesar 61.8\%, sedangkan sisanya sebesar 38.2\% dipengaruhi oleh variabel bebas lain yang tidak diteliti. Secara parsial variabel Capital Adequancy Ratio tidak signifikan berpengaruh terhadap Return On Assets perusahaan perbankan di Bursa Efek Indonesia. Penelitian ini mengindikasikan bahwa setiap perubahan rasio kecukupan modal perusahaan tidak signifikan berpengaruh pengaruh terhadap jumlah Return On Assets yang dihasilkan perusahaan. Secara teoritis Capital Adequancy Ratio adalah rasio yang memperlihatkan seberapa jauh seluruh aktiva bank yang mengandung risiko (kredit, penyertaan, surat berharga, tagihan pada bank lain) ikut dibiayai dari dana modal sendiri bank disamping memperoleh dana-dana dari sumber diluar bank, seperti dari masyarakat, pinjaman, dan lain-lain. Variabel Debt To Equity Ratio secara statistik tidak signifikan berpengaruh terhadap Return On Assets perusahaan, hal ini mengindikasikan bahwa setiap perubahan rasio hutang perusahaan tidak memberikan pengaruh terhadap jumlah return on assets yang dihasilkan perusahaan. Variabel Loan to Deposit Ratio pada penelitian ini tidak berpengaruh terhadap Return On Assets perusahaan, hal ini mengindikasikan perubahan rasio jumlah kredit yang diberikan dengan jumlah dana yang dikumpulkan dari masyarakat tidak memberikan pengaruh terhadap return on assets.
\end{abstract}

\begin{abstract}
The results of the study, the coefficient of determination $\left(R^{2}\right)$ of 0.618 , not multiple $(R)$ of 0.786 , shows that the contribution of variables that are given freely is the Capital Adequancy Ratio, Debt To Equity Ratio, Loan To Deposit Ratio and Earning Per Share to return on assets of 61.8\%, while the remaining $38.2 \%$ was revealed by other independent variables which were not studied. Partially the Capital Adequancy Ratio variable has no significant effect on the Return On Assets of banking companies on the Indonesia Stock Exchange. This study indicates that any change in the company's capital adequacy ratio has no effect on the amount of Return On Assets that the company produces. Theoretically the Capital Adequancy Ratio is the ratio that previously all bank assets that contain risk (credit, investment, securities, claims on other banks) are also financed from the bank's own capital funds in addition to obtaining funds from sources outside the bank, such as from the public, loans, and etc. The variable Debt To Equity Ratio statistically has no significant effect on the company's return on assets, this indicates that any change in the company's debt ratio does not have an effect on the amount of return on assets that the company produces. The Loan to Deposit Ratio variable in this study has no effect on the company's Return on Assets, this indicates that the change in the ratio of the amount of loans granted to the amount of funds collected from the public has no effect on return on assets.
\end{abstract}

\section{Keywords: Capital Adequancy Ratio, Debt To Equity Ratio,Loan To Deposit Ratio dan Earning Per Share}

\section{PENDAHULUAN}

Pasar modal merupakan salah satu alternatif pilihan sumber dana jangka panjang bagi perusahaan yang sudah listed, baik sector manufacture, kimia, tambang maupun sektor perbankan. Bagi investor merupakan hal yang sangat penting untuk mengetahui kinerja perbankan salah satunya adalah dengan analisis rasio keuangan dari perusahaan tersebut. yang dimilikinya untuk memperoleh laba.

Dalam mencapai tingkat profitabilitas yang tinggi, dalam bisnis perbankan dapat dipengaruhi oleh faktor internal yang terdiri dari rasio Capital Adequancy Ratio, Debt to Equity Ratio, Loan to Deposit Ratio, dan Earning per share. Dimana Penetapan Capital Adequacy Ratio (CAR) sebagai variabel yang mempengaruhi profitabilitas didasarkan hubungannya dengan tingkat risiko bank. 


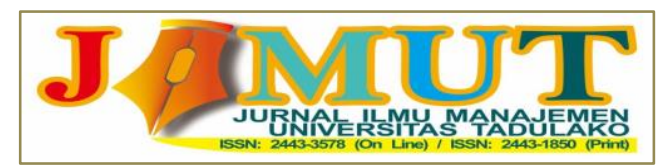

Vol. 6, No.3, September 2020, 272-278

Berdasarkan dengan uraian latar belakang diatas,sertafenomena yang terjadisekarang maka dilakukan penelitian dengan mengambiljudul "Analisis Pengaruh Capital Adequancy Ratio,Debt to Equit Ratio,Loan to Deposit Ratio, dan Earning Per ShareTerhadap Return On Asset(Studi pada Bank Umum Konvensional yang Terdaftar di Bursa Efek Indonesia Periode 2014-2017).”

Pasar modal merupakan salah satu alternatif pilihan sumber dana jangka panjang bagi perusahaan yang sudah listed, baik sector manufacture, kimia, tambang maupun sektor perbankan.

Bagi investor merupakan hal yang sangat penting untuk mengetahui kinerja perbankan salah satunya adalah dengan analisis rasio keuangan dari perusahaan tersebut. yang dimilikinya untuk memperoleh laba.

Dalam mencapai tingkat profitabilitas yang tinggi, dalam bisnis perbankan dapat dipengaruhi oleh faktor internal yang terdiri dari rasio Capital Adequancy Ratio, Debt to Equity Ratio, Loan to Deposit Ratio, dan Earning per share. Dimana Penetapan Capital Adequacy Ratio (CAR) sebagai variabel yang mempengaruhi profitabilitas didasarkan hubungannya dengan tingkat risiko bank.

Berdasarkan dengan uraian latar belakang diatas,sertafenomena yang terjadisekarang maka dilakukan penelitian dengan mengambiljudul "Analisis Pengaruh Capital Adequancy Ratio,Debt to Equit Ratio,Loan to Deposit Ratio, dan Earning Per ShareTerhadap Return On Asset(Studi pada Bank Umum Konvensional yang Terdaftar di Bursa Efek Indonesia Periode 2014-2017).”

\section{Pengertian Perbankan}

Definisi Bank menurut Undang-Undang RI Nomor 10 Tahun 1998 adalah badan usaha yang menghimpun dana dari masyarakat dalam bentuk simpanan dan menyalurkannya kepada masyarakat dalam bentuk kredit dan atau bentuk-bentuk lainnya dalam rangka meningkatkan taraf hidup rakyat banyak. Lembaga keuangan menyalurkan kredit kepada nasabah atau menginvestasikan dananya dalam surga berharga di pasar keuangan (Financial Market).

Penggolongan bank tidak hanya berdasarkan jenis kegiatan usahanya, melainkan juga mencakup bentuk badan hukum, pendirian dan kepemilikan, segi status, cara menentukan harga, fungsi dan tujuan usahanya. Analisis laporan keuangan adalah analisis mengenai dua daftar yang disusun oleh akuntan pada akhir periode untuk suatu perusahaan. Kedua daftar itu adalah daftar neraca/laporan posisi keuangan dan daftar pendapatan/daftar laba rugi. Laporan keuangan yang dibuat oleh perusahaan terdiri dari beberapa jenis, tergantung dari maksud dan tujuan pembuatan laporan keuangan.Masing-masing laporan keuangan memiliki arti sendiri dalam melihat kondisi keuangan perusahaan, baik secara bagian, maupun secara keseluruhan.

Tujuan analisis laporan keuangan mempunyai beberapa tujuan penting untuk dipahami oleh pemakai laporan keuangan. Tujuan analisis laporan keuangan yang telah diungkapkan oleh beberapa ahli, dapat peneliti simpulkan tujuannya adalah untuk menjadi alat dalam pengambilan keputusan. Keputusan yang dimaksud berupa langkah perbaikan dalam kelemahan perusahaan, untuk penilaian kinerja perusahaan, pembanding hasil yang dicapai dan mengetahui kekuatan perusahaan.

Ukuran yang digunakan untuk mengetahui kesehatan bank dan mengetahui kondisi keuangan bank dilihat dari laporan keuangan yang disajikan oleh bank secara periodik. Dalam laporan keuangan yang dibuat bank menggambarkan kinerja bank selama periode tertentu. Pengolahan laporan keuangan

dibuat sesuai dengan standar yang telah ditetapkan. Analisis yang digunakan dalam hai ini menggunakan rasio-rasio keuangan sesuai dengan standar yang berlaku. Pada umumnya, analisis rasio keuangan dapat dibedakan menjadi beberapa jenis :

1. Rasio Likuiditas

Rasio ini digunakan untuk mengukur kemampuan bank dalam memenuhi kewajiban jangka pendek. Dengan catatan semakin besar rasio likuiditas maka semakin likuid. Perhitungan rasio likuiditas dengan cara:

2. Rasio Solvabilitas

Rasio ini digunakan mengukur kemempuan bank mencari sumber dana untuk membiayai kegiatan bank atau alat ukur untuk melihat kekayaan bank serta melihat efisiensi pihak manajemen bank. Perhitungan rasio ini dilakukan dengan cara :

3. RasioRentabilitas

Rasio ini digunakan untuk mengukur tingkat efisiensi usaha dan profitabilitas yang dicapai oleh bank. Perhitungan rasio ini dilakukan dengan cara : 


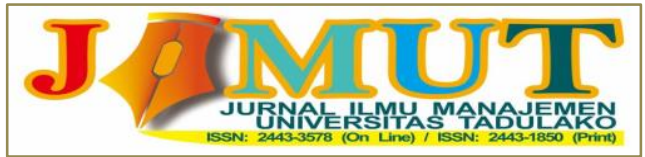

Vol. 6, No.3, September 2020, 272-278

Dalamperbankan untuk mengetahuiukuran profitabilitas biasa yang digunakan adalah ROA/Return On Asset. Rasio ini untuk digunakan untuk mengukur kemampuan perusahaan untuk memperoleh earning dalam operasi perusahaan. Pada dasarnya ROA/Return On Asset merupakan rasio antara laba setelah pajak terhadap total asset. Semakin besar ROA/Return On Asset menunjukkan kinerja keuangan yang semakin baik,karena tingkat pengembalian (return) semakin besar. Apabila ROA/Return On Asset meningkat, berarti profitabilitas perusahaan meningkat, sehingga dampak akhirnya adalah peningkatan kesejahteraan yang dinikmati oleh pemegang saham.

$\mathrm{H}_{1}=\mathrm{CAR}$, DER, LDR, dan EPS berpengaruh secara simultan terhadap ROA

$\mathrm{H} 2$ = CAR, DER,LDR, dan EPS berpengaruh secara parsial terhadap ROA

\section{METODE PENELITIAN}

Penelitian ini data yang dipergunakan adalah data sekunder berupa data time series untuk semua variabel yaitu Return On Asset (ROA) dan data rasio-rasio keuangan masing-masing perusahaan perbankan yaitu Capital Adequacy Ratio (CAR), Debt to Equity Ratio (DER), Loan to Deposit Ratio (LDR), dan Earning Per Share (EPS) yang terdaftar di Bursa Efek Indonesia. Data sekunder ini diperoleh dengan metode pengamatan saham-saham yang terdaftar selama pengamatan dari tahun 2014-2017.

Sumber data dalam penelitian ini merupakan data sekunder yang diperoleh secara historis,dimana diperoleh dari Laporan Keuangan Publikasi yang diterbitkan oleh Bursa Efek Indonesia (www.idx.com). Periodesasi data menggunakan data Laporan Keuangan Publikasi Tahunan periode tahun 2014-2017.

Populasi dalam penelitian ini adalah perusahaan perbankan yang tercatat di Bursa Efek Indonesia (BEI) tahun 2014-2017. Jumlah populasi dalam penelitian ini adalah sebanyak 45 bank. Teknik pengambilan sampel dilakukan melalui metode purposive sampling dengan tujuan untuk mendapatkan sampel yang sesuai dengan tujuan penelitian. Metode purposive sampling merupakan metode pengambilan sampel yang didasarkan pada beberapa pertimbangan atau kriteria tertentu.

\section{Analisis Regresi liner berganda}

Teknik analisa yang dipakai dalam penelitian ini adalah dengan memakai teknik analisa regresi linier berganda untuk memperoleh gambaran yang menyeluruh mengenai hubungan antara variabel satu dengan variabel yang lain. Dalam hal ini untuk variabel dependennya adalah Return On Asset (ROA) dan variabel independennya Capital Adequacy Ratio (CAR), Debt to Equity Ratio (DER)Loan to Deposit Ratio (LDR), dan Earning Per Share (EPS). Untuk mengetahui apakah ada pengaruh yang signifikan dari variabel independen terhadap variabel dependen maka digunakan model regresi linier berganda (multiple linier regression method), yang dirumuskan sebagai berikut:

$\mathrm{Y}=\alpha+\mathrm{b}_{1} \mathrm{X}_{1}+\mathrm{b}_{2} \mathrm{X}_{2}+\mathrm{b}_{3} \mathrm{X}_{3}+\mathrm{e} \ldots \ldots$.

Dimana :

$\mathrm{Y} \quad=$ Return On Assets (ROA)

$\alpha \quad=$ Konstanta

$\mathrm{X}_{1} \quad=$ Capital Adequancy Ratio (CAR)

$\mathrm{X}_{2} \quad=$ Debt to Equity Ratio (DER)

$\mathrm{X}_{3}=$ Loan to Deposit Ratio (LDR)

$\mathrm{X}_{4}=$ Earning Per Share $($ EPS)

$\mathrm{b}_{1}-\mathrm{b}_{3} \quad=$ Koefisien Regresi

e $\quad=$ error term 


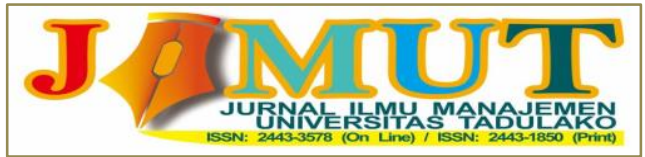

Vol. 6, No.3, September 2020, 272-278

\section{Uji t (Uji Parsial)}

Uji $\mathrm{t}$ dilakukan untuk mengukur sejauh mana pengaruh dan signifikan variable bebas dalam memberikan kontribusi terhadap variable terikat atau tergantung secara individual parsial.

a. Jika t terhitung $\leq \mathrm{t}$ tabel, maka variable independen secara individual /parsial tidak berpengaruh terhadap variable dependen

b. Jika t terhitung $>\mathrm{t}$ tabel, maka variable independen secara individual/parsial berpengaruh terhadap variable dependen

Keputusan yang diambil pada uji t bisa dilakukan dengan melihat nilai signifikan taraf kepercayaan $(5 \%)=0,05$. Jika nilai signifikannya $\geq 0,05$ maka variable bebas (independen) tidak berpengaruh signifikan terhadap variable terikat (dependen). Sedangkan jika nilai signifikannya $<0,05$ , artinya variable independen berpengaruh signifikan terhadap variable dependen.

\section{Uji F}

Pengujian simultan dengan menggunakan uji statistij F (uji F) dilakukan untuk mengukur sejauh mana pengaruh dan singkat signifikan variabel independen secara simultan dalam memberikan kontribusi terhadap variabel dependen.

Kriteria pengambilan keputusan sebagai berikut :

1. Jika $\mathrm{F}$ terhitung $<\mathrm{F}$ tabel, maka variabel independen secara simultan tidak berpengaruh signifikan terhadap variabel dependen

2. Jika $\mathrm{F}$ hitung > F tabel, maka variabel independen secara simultan berpengaruh signifikan terhadap variabel dependen

Uji Koefisien Determinasi $\left(\mathbf{R}^{2}\right)$

Koefisien determinasi $\left(\mathrm{R}^{2}\right)$ digunakan untuk mengetahui sampai seberapa besar variabel bebas pada model dapat diterangkan oleh variabel terikat (Gujatari,1995).

\section{HASIL DAN PEMBAHASAN \\ Pengujian Hipotesis Secara Simultan}

Berdasarkan dari pengujian, dapat disimpulkan bahwa pengujian terhadap Ho ditolak. Hal ini seperti ditunjukkan dengan besarnya $\mathrm{F}$ hitung sebesar 30.368 lebih besar dari $\mathrm{F}$ Tabel (n-k-1) pada tarf nyata $(\alpha=0,05)$ dan df (4:80) sebesar 2.751Dengan ditolaknya Ho dan diterimanya Ha, berarti secara empiris yang menyatakan variabel bebas mempunyai kecenderungan hubungan positif dan bermakna terhadap variabel terikat, juga diterima. Dengan demikian nilai koefisien determinasi $\left(\mathrm{R}^{2}\right)$ sebesar 0,618 koefisien korelasi berganda (R) 0,786 menunjukkan bahwa sumbangan yang diberikan variabel bebas yaitu Capital Adequancy Ratio, Debt To Equity Ratio,Loan To Deposit Ratiodan Earning Per Shareterhadap return on assets sebesar 61.8\%, sedangkan sisanya sebesar $38.2 \%$ dipengaruhi oleh variabel bebas lain yang tidak diteliti.

\section{Analisis Regresi Berganda}

Persamaan garis regresi untuk penelitian ini yaitu : $\mathrm{Y}=0.35+0.008 \mathrm{X}_{1}+0.010 \mathrm{X}_{2}+0.036 \mathrm{X}_{3}+0.784 \mathrm{X}_{4}$

Berdasar hasil uji t dapat diketahui bagaimana pengaruh variabel Capital Adequancy Ratio, Debt To Equity Ratio, Loan To Deposit Ratio dan Earning Per Share secara parsial terhadap Return On Assets. Hasil penelitian diketahui bahwa variabel yang mempunyai pengaruh dan signifikan terhadap return on assets yaitu variabel earning per share, sedangkan variabel Capital Adequancy Ratio, Debt To Equity Ratio dan Loan To Deposit Ratio tidak signifikan pengaruhnya terhadap return on assets.

Koefisien regresiCapital Adequancy Ratio (XI)sebesar 0.008 menunjukkan besarnya pengaruh perubahan Capital Adequancy Ratioterhadap Return On Assets. Pengaruh positif menunjukkan pengaruh yang searah antara perubahan Capital Adequancy Ratiodengan perubahan Return On Assets. Dengan kata lain, jika Capital Adequancy Ratio meningkat satu satuan menyebabkan naiknya Return On Assets sebesar 0.008 dengan anggapan variabel lainnya tetap (konstan).

Koefisien regresi Debt To Equity Ratio (X2) sebesar 0.010 menunjukkan besarnya pengaruh perubahan Debt To Equity Ratioterhadap Retun On Assets. Pengaruh positif menunjukkan pengaruh 


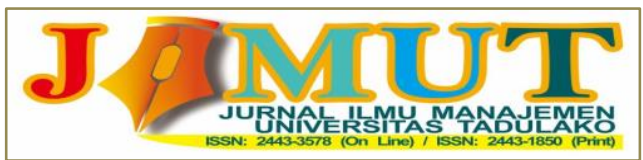

Vol. 6, No.3, September 2020, 272-278

yang searah antara perubahan Debt To Equity Ratio dengan perubahan retun on assets. Dengan kata lain, jika Debt To Equity Ratio meningkat satu satuan menyebabkan naiknya Return On Assets sebesar 0.010dengan anggapan variabel lainnya tetap (konstan).

Koefisien regresi Loan To Deposit Ratio ( $\square 3$ ) sebesar 0.036 menunjukkan besarnya pengaruh perubahan Loan To Deposit Ratio terhadap Return On Assets. Pengaruh positif menunjukkan pengaruh yang searah antara perubahan Loan To Deposit Ratio dengan perubahan return on assets. Dengan kata lain, jika Loan To Deposit Ratio meningkat satu satuan menyebabkan naiknya Return On Assets sebesar 0.036 dengan anggapan variabel lainnya tetap (konstan).

Koefisien regresi Earning Per Share $(\square 4)$ sebesar 0.784 menunjukkan besarnya pengaruh perubahan Earning Per Shareterhadap return on assets. Pengaruh positif menunjukkan pengaruh yang searah antara perubahan Earning Per Share dengan perubahan Return On Assets. Dengan kata lain, jika Earning Per Sharemeningkat satu satuan menyebabkan naiknya return on assets sebesar 0.036 dengan anggapan variabel lainnya tetap (konstan).

\section{Pembahasan Hasil Penelitian}

Hasil penelitiansecara simultan diketahui bahwa ada pengaruh secara simultan (serempak) variabel bebas penelitian terhadap return on assets perusahaan industri perbankan yang terdaftar di Bursa Efek Indonesia. Adanya pengaruh secara simultan mengindikasikan kinerja yang dihasilkan perusahaan sangat berpengaruh terhadap Return On Assets perusahaan perbankan di pasar modal.

Earning Per Share secara parsial merupakan variabel yang berpengaruh terhadap Return On Assets sedangkan Capital Adequancy Ratio,Debt To Equity Ratio dan Loan To Deposit Ratio tidak berpengaruh terhadap Return On Assets perusahaan perbankan di Bursa Efek Indonesia. Hasil penelitian ini mengindikasikan bahwa setiap perubahan laba perlembar saham perusahaan sangat pengaruh terhadap jumlah Return On Assets yang dihasilkan perusahaan. Pengaruh yang positif mengandung arti bahwa setiap kenaikan laba perlembar saham perusahaan maka akan menaikan Return On Assets perusahaan. Secara teoritis menurut Tjiptono (2012) menyatakan semakin tinggi nilai EPS akan menggembirakan pemegang saham karena semakin besar laba yang disediakan untuk pemegang saham.

Secara parsial variabel Capital Adequancy Ratio tidak signifikan berpengaruh terhadap Return On Assets perusahaan perbankan di Bursa Efek Indonesia. Hasil penelitian ini mengindikasikan bahwa setiap perubahan rasio kecukupan modal perusahaan tidak signifikan berpengaruh pengaruh terhadap jumlah Return On Assets yang dihasilkan perusahaan. Secara teoritis Capital Adequancy Ratio adalah rasio yang memperlihatkan seberapa jauh seluruh aktiva bank yang mengandung risiko (kredit, penyertaan, surat berharga, tagihan pada bank lain) ikut dibiayai dari dana modal sendiri bank disamping memperoleh dana-dana dari sumber diluar bank, seperti dari masyarakat, pinjaman, dan lain-lain (Dendawijaya, 2000). Hasil penelitian ini tidak sejalan dengan penelitian yang dilakukan oleh Pranata (2015) dan Suryani (2016) yang menyebutkan bahwa Capital Adequancy Ratio berpengaruh terhadap Return On Assets perusahaan perbedaan ini dimungkinkan perbedaan objek penelitian dan periode penelitian sehingga diperlukan penelitian lanjutan untuk mendapatkan konsistensi hasil penelitian.

Variabel Debt To Equity Ratiopada penelitian ini secara statistik tidak signifikan berpengaruh terhadap Return On Assets perusahaan, hal ini mengindikasikan bahwa setiap perubahan rasio hutang perusahaan tidak memberikan pengaruh terhadap jumlah return on assets yang dihasilkan perusahaan. Secara teoritis variabel Debt To Equity Ratio berpengaruh negatif terhadap Return On Asset perusahaan, karena setiap penambahan rasio solvabilitas perusahaan akan memberikan efek negatif terhadap besarnya Return On Assets perusahaan di pasar modal.

Variabel Loan to Deposit Ratio pada penelitian ini tidak berpengaruh terhadap Return On Assets perusahaan, hal ini mengindikasikan perubahan rasio jumlah kredit yang diberikan dengan jumlah dana yang dikumpulkan dari masyarakat tidak memberikan pengaruh terhadap return on assets. Secara teoritis Loan To Deposit Ratio sebagai rasio untuk mengukur komposisi jumlah kredit yang diberikan dibandingkan dengan jumlah dana masyarakat dan modal sendiri yang digunakan (Kasmir, 2012). Hasil penelitian ini tidak sejalan dengan teori yang ada, dimungkinkan karena pendeknya 


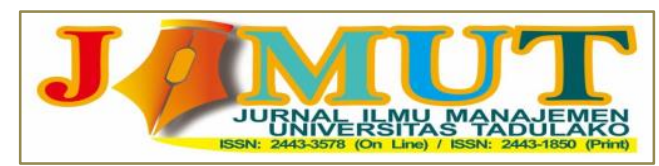

Vol. 6, No.3, September 2020, 272-278

periode penelitian dan kecilnya sampel perusahan yang diteliti, sehingga diperlukan penelitian lanjutan guna mengetahui konsistensi penelitian ini dengan penelitian selanjutnya.

\section{Simpulan}

1. Penelitian ini bertujuan untuk mengetahui pengaruh simultan dan parsial variabel Capital Adequancy Ratio, Debt To Equity Ratio, Loan To Deposit Ratiodan Earning Per Share terhadap Return On Assets dengan menggunakan konsep dan teori rasio keuangan perusahaan.

2. Hasil pengujian hipotesis pertama diketahui ada pengaruh secara simultan variabel penelitian yang terdiri Capital Adequancy Ratio, Debt To Equity Ratio, Loan To Deposit Ratio dan Earning Per Share terhadap Return On Assets yang ditunjukkan besarnya nilai f-hitung daripada f-tabel dengan demikian hipotesis pertama menerima $\mathrm{H}_{\mathrm{a}}$ dan menolak $\mathrm{H}_{0}$.

3. Pengujian hipotesis kedua diketahui variabel penelitian earning per sharesecara parsial berpengaruh terhadap return on assets, sedangkan variabel Capital Adequancy Ratio, Debt To Equity Ratio dan Loan To Deposit Ratio tidak berpengaruh terhadap Return On Assets. Hasil penelitian ini juga menempatkan variabel Earning Per Share merupakan variabel yang berpengaruh dominan terhadap Return On Assets karena variabel Earning Per Share satu-satunya variabel yang diteliti berpengaruh terhadap Return On Assets perusahaan perbankan di Bursa Efek Indonesia.

\section{Saran}

Adapun saran yang dapat di ajukan penulis sebagai berikut :

1. Perlu menambah variabel independen yang potensial memberikan kontribusi terhadap variabel Return On Assets perusahaan, dan juga perlu menambah periode pengamatan.

2. Dapat diperluas lagi dengan memasukkan variabel yang yang mempengaruhi tingkat keuntungan perusahaan.

3. Pihak perbankan harus terus memperhatihkan faktor-faktor yang mempengaruhi kepurusan investor dalam pembelian saham karena hal ini akan mencerminkan kinerja dan nilai persuhaan itu sendiri.

\section{DAFTAR PUSTAKA}

Ali, Masyhud.2006. Manajemen Risiko:Strategi Perbankan dan Dunia Usaha Menghadapi Tantangan Globalisasi Bisnis.PT. RajaGrafindo Persada. Jakarta

Bank Indonesia. 1998. UU No.10 tahun 1998, Tentang Perubahan Terhadap UU No. 7 tahun 1992, Jakarta

Dendawijaya, Lukman.2005.Manajemen Perbankan. Ghalia Indonesia. Bogor

Dendawijaya, L. 2009. Manajemen Perbankan, Edisi 2. Ghalia Indonesia. Bandung.

Dewi, Purnama S dan Juniati Gunawan, 2003, Analisis Tingkat Kesehatan Bank Dan Luas Pengungkapan Peristiwa Setelah Tanggal Neraca Pada Laporan Tahunan Perbankan yang Terdaftar Di BEJ, Media Riset Akuntansi, Auditing, Dan Informasi, Vol. 3, No. 2, agustus 2003 : $155-180$.

Dietrich, A dan G. Wanzenried. 2011. "Determinants of Bank Profitability Before and During The Crisis: Evidence from Switzerland". Journal of International Financial Markets, Institutions and Money, Vol. 21, hlm 307-327

Ghozali, I. 2005. Aplikasi Analisis Multivariate Dengan Program SPSS, Cetakan Keempat. Badan Penerbit Universitas Diponegoro. Semarang.

Harahap, Sofyan Syafri. 2009. “Analisis Kritis Atas Laporan Keuangan”. Jakarta: RajaGrafindo Persada.

Harahap Sofyan Syafri (2011), Teori Akuntansi Edisi Revisi 2011. Jakarta: Rajawali Pers.

Kasmir. 2003. Bank dan Lembaga Keuangan. Jakarta: PT. Raja Grafindo Persada 


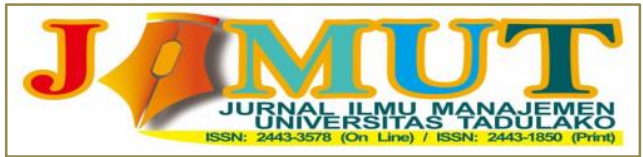

Vol. 6, No.3, September 2020, 272-278

Kasmir. 2012b. Manajemen Perbankan, Edisi Revisi, Cetakan 11. PT Raja Grafindo Persada. Jakarta Kasmir. (2014). Dasar-Dasar Perbankan. Edisi Revisi, Cetakan ke duabelas, PT. RajaGrafindo

Persada, Jakarta.

Moeljadi. 2006. Manajemen Keuangan. Pendekatan Kuantitatif dan Kualitatif, Edisi Pertama. Bayu Media Publishing, Malang.

Munawir (2010), Analisa Laporan Keuangan, Edisi Ke-4. Yogyakarta: Liberty.

Sufian, F. 2011. "Profitability of The Korean Banking Sector: Panel Evidence on Bank Specific and Macro Economics Determinant". Journal of Economics and Management, Vol. 7, No. 1, hlm 43- 72. www.idx.com 